\title{
DEVELOPING READING SKILLS IN A FLIPPED CLASS: AN ALGORITHM
}

Developing reading skills is one of the main goals in the university ESP class since nowadays students have to process substantial amounts of information in academic settings and throughout their future career. The current shift in high education paradigm challenges teachers to refocus their teaching strategies and adopt new approaches to make the learning process rewarding in the modern context. Flipped class approach is claimed to have a great potential to provide a refreshing view for the ESP teaching and bring the learning process the new level of efficiency. Therefore, the approach is getting more and more attention from practitioners and researchers. Recent researches report a generally positive impact of the model on students learning outcomes, attitudes and level of satisfaction compared to the traditional models. However, developing reading skills and utilizing text-based activities are not very common in a flipped class model since it is highly associated with video. The lack of clarity about feasibility of this mode for developing reading skills and low technical expertise are among the most common reasons why teachers are hesitant to adopt flipped class model in their practice. The current paper presents the implementation algorithm of flipped reading for an ESP course. In addition, the possible option addressing the lack of technical expertise is described. As a technical solution, the platform Wizer.me is presented in the current paper. The platform offers free tools for designing interactive reading worksheets and provides special features such as adding audio content, video, links and images to the worksheets. The service enables teachers to gain insights on the students' progress and status and offer a feedback. Special features offered by the platform allow approaching each student individually and give good opportunities for students'self-analysis as a crucial component of developing the skills of reflection and critical evaluation. Having user-friendly interface, the Wizer.me platform is available to use by the teachers with the basic level of computer literacy.

Key words: ESP, reading, flipped class, technical solution, algorithm, stages, Wizer.me.

Reading is one the core skills for university students, as they have to absorb massive amounts information in academic settings and throughout their future career. Nowadays, English is the medium in every domain of communication, both in local and global contexts and it is becoming increasingly true as international relations are expanding. Since the majority of the topical information is provided in English, it is used for the purposes of academic, career and social productive performance. Therefore, developing reading skills is one of the main goals in the university ESP class.

Nowadays, developing reading skills still falls on the premise of traditional teaching mode, where students develop their reading skills and work with content under the guidance of a teacher in a class. However, the current shift in education paradigm tasks teachers to refocus their teaching strategies and adopt new approaches to meet new challenges, incorporate facilitative technologies and to provide models and opportunities for effective and ample practice. In this context, the flipped class approach is getting more and more attention from practitioners and researchers.

Recent researches present the flipped class as an approach, which has a great potential to improve students' learning experience and improve the efficiency of the learning process $[2 ; 4 ; 7 ; 9 ; 12]$. Flipped class approach is gaining its popularity for ESP teaching and developing different skills in university settings $[1 ; 3 ; 9 ; 11 ; 12]$. However, developing reading skills and utilizing text-based activities are not very common in a flipped class model since it is highly associated with video. The lack of clarity about feasibility of this mode for developing reading skills and low technical expertise are among the most common reasons why teachers are hesitant to adopt flipped class model in their practice.

The study aims to report the findings about the technical solution for providing out-of-class content and to present the successfully implemented algorithm for flipping reading ESP course component in the real university settings.

This study presents the four-stage model to flip the reading elements of the ESP curriculum: introduction, preclass, in-class and post-class stages.

The participants were a group of students taking the ESP course in academic year 2020/2021. There were 52 students in their fifths term. This selection was reasoned by the following factors: students in their fifths term: 1) have enough learning experience and 2) mature enough in age. The implementation period lasted 12 weeks. Students and teachers met in a class for 90 minutes once a week.

As a medium for tasks delivery, the platform Wizer.me was used.

Since developing reading skills in a flipped mode does not impose passive reading, simple selection of the appropriate text content is not enough. It is crucial to offer activities that motivate and encourage students to invest their time and efforts to read and learn. Students need to understand the sense in the offered activities and connect them to instructional goals. In other case, it will be just another homework exercise [3;9; $10 ; 13]$. As the major challenge of flipping reading is to avoid passiveness, it necessary to make it interactive. Nowadays, teachers have an access to a grate array of services which can be used to create interactive multimedia worksheets such as Google services, LearningApps, MasterTest, Socrative, ClassTime etc. Having analyzed the key features, pricing, availability and technical requirements we chose the platform Wizer.me as the most suitable for us.

Wizer.me is an education platform that enables teachers to create interactive digital worksheets from scratch, to use ready-made worksheets or to adopt them to any course since an extensive and constantly updated library 
of resources is available. Teachers have an opportunity to share their worksheets, assign them to students, asses students' answers and keep track of students' performance.

The service is free and the amount of worksheets is not limited. The Wizer.me service is available on any computer of mobile device with the Internet connection and can be run in any browser.

To register, teachers and students can use Google accounts that simplifies the procedure or sign up using any email. In addition, the service is integrated with OneNote Class Notebook (Microsoft One Note) and users can use their logins for access. The worksheets can be embedded into OneNote Class Notebooks; delivered via Google Classroom or Embodo; pasted in a teacher's blog, webpage or any service used; accessed through the link or code sent by a teacher. The service offers two access options: 1) as a teacher (with features for creating content and evaluating the results) and 2) as a student (access only to the content).

To create a worksheet the service offers a list of questions types (pic.1) enabling to create a wide variety of tasks.

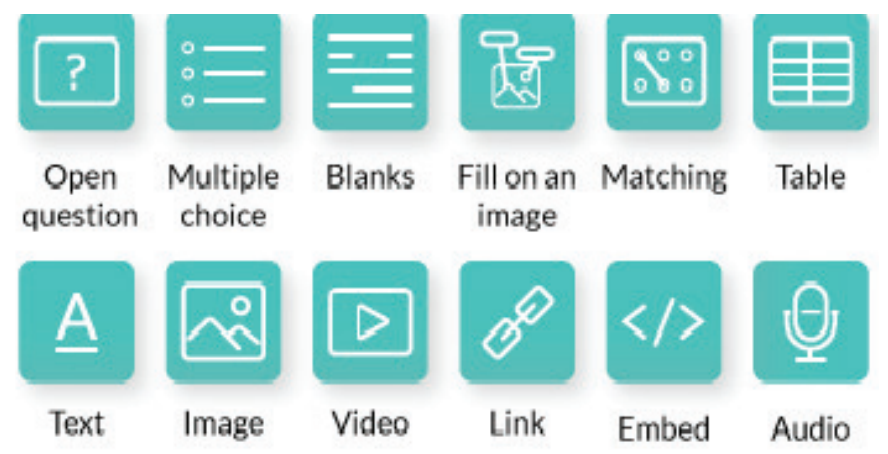

Pic. 1. Question Types

Worksheet may contain the following activities:

- open-ended tasks: where students are to present their answers in the textual format, as picture or an audio message;

- multiple choice questions: require students to choose the best option (textual format and/or images) from a list of answers;

- blanks: students are supposed to fill in the gaps to complete the text/statements;

- a task based on an image: students are to add captions in particular sections;

- matching: textual elements are to be paired/grouped (this may be individual words, words and definitions, parts of sentences, pictures to words etc.);

- chart/table completing: information is presented in cells proposing only one option: «Instruction» (e.g. a task delivered to students in a mode allowing its completion) or «Key answers» (e.g. the correct answer - the cell is empty, and students are to fill it);

- sorting: categories a list of textual elements are presented to students and they are to distribute the elements between the categories;

- drawing: students can draw their response in the simplest embedded graphics editor or add to the generated picture images and text messages;

- texting: a formatted text message.

Tasks can be supplemented by adding any rich media (video, audio, animated GIFs, images) and hyperlinks directly to an interactive worksheet. Teachers can also record their own instructions or explanations without using and third-party services.

At the stage of shaping and/or editing teachers can: grade the level of assimilation; introduce a list of keywords for content; choose the design; title a worksheet.

Almost all activities have an auto-check option and can be assessed automatically (number of points can be set by a teacher for answer). It is possible to textual or audial comments to each task. The automatic messaging function can be used to inform students about the results immediately after handing a worksheet («Automatic feedback to students» button). Students' answers and scores can be exported in .csv files with full answers or just general statistics.

One more important feature is that each student has a personal profile. Students' attributes include the classes they enrolled in, differentiation rules that teachers can apply to the students for worksheets and descriptions of the students' strengths, progress, performance summary etc. Students have free access to their profiles too (except the bottom teacher's note), which facilitates self-analysis. This option allows communication via personal messages providing individual support and feedback and view students' performance.

Having summarized the options and features mentioned above, we are able to conclude that the Wizer.me service fully meet the requirements and principles of ESP teaching and flipped mode approach, therefore it can be used to flip the reading ESP course component. 


\section{The algorithm for flipping reading ESP course component.}

\section{Introduction stage.}

At the beginning, the participants were provided with the detailed explanation part: the objectives and the rationale of the flipped mode was explained; the platform Wizer.me was introduced; the detailed instructions were delivered. The main goal of this stage was to eliminate the potential obstacles related to the students' incomprehension, reluctance, reservations and disengagement $[2 ; 6 ; 9 ; 14]$. The instructional time focused on routines and procedures giving students time to learn how to succeed in this new format was one of the core elements of the stage.

Pre-class Stage: a self-study on Wizer.me.

Pre-class activities were aimed to help students to explore course content individually (its reading component). Knowledge construction was realized individually in an out-of-class mode. Students were tasked to work with digital interactive worksheets on the platform Wizer.me.

Since teachers' role was still crucial, we provided permanent support and directions to every student to alleviate the potential stress and help to succeed $[2 ; 3 ; 9 ; 10 ; 14]$. The platform also enabled us to gain insights on the students' progress and status and offer them a feedback. Furthermore, having monitored students' pre-class performance, we conducted in-class activities based on misunderstandings and high-error-rate questions.

In-class stage: collaboration and team activities, role-plays, discussions.

Since flipped class format enabled students to review the materials before the class and then, having all the fundamental information, they participated in interactive learning activities that pushed them to apply their knowledge in practice $[5 ; 10]$. The reserved in-class time was utilized for teamwork, comprehension tasks, in-depth analysis and discussions, collaborative or individual assignments etc. It fostered the increased peer interaction environment, activities focused on higher cognitive learning, developing their critical thinking, analysis and problem solving, skills $[2 ; 4 ; 5 ; 9]$.

As for the first and vital in-class activity in every session the brief review on the pre-class material was held to recall students' memory and clarify any misunderstanding. As for the final in-class activity, a brief preview on the out-of-class material for the next lesson was presented to promote students' interest and engagement.

Post-class stage: formative assessment and self-assessment.

The post-class stage aimed to provide students with opportunities to analyze their performance and progress. Self-analysis addressed in the responsibility for their own learning success and was aimed to facilitate: 1) developing the skills of reflection and critical evaluation; 2) identifying gaps in knowledge and performance; 3) prompting the ways for improving their performance.

Formative assessment enabled teachers to identify students' needs and progress improve instruction process via targeting areas that need work.

Conclusions. The results obtained in our practice (feedback surveys and interviews, formative and summative assessment activities) support the assumption that the approach has a great potential to affect the ESP class positively. Flipped mode has a great potential to foster developing reading skills within an ESP course. Being implemented appropriately and suitably, the approach can enrich the traditional learning process and make it more productive and student-centred. It is compatible with the regular curriculum and has a good potential to reform the traditional time-consuming in-class components of the ESP course and make it more topical and motivating. However, the process of implementing new formats of training requires careful planning, proper design and monitoring the students' and teachers' feedback to detect and correct possible shortcomings.

\section{Bibliography:}

1. Chua J. S. M., Lateef F. A. The flipped classroom: viewpoints in Asian universities. Education in Medicine Journal. 2014. No. 6 (4). Pp. 20-26. DOI: 10.5959/eimj.v6i4.316.

2. Clark K. R. The effects of the flipped model of instruction on student engagement and performance in the secondary mathematics classroom. Journal of Educators Online. 2015. No. 12(1). Pp. 91-115. DOI: 10.9743/JEO.2015.1.5.

3. Flores O., del-Arco I., \& Silva P. The flipped classroom model at the university: Analysis based on professors' and students' assessment in the educational field. International Journal of Educational Technology in Higher Education. 2016. No. 13(1), Pp. 1-12. DOI:10.1186/s41239-016-0022-1.

4. Goedhart N.S., Blignaut-van Westrhenen N., Moser C. et al. The flipped classroom: supporting a diverse group of students in their learning. Learning Environments Research. 2019. No. 22. Pp. 297-310. DOI:10.1007/s10984-019-09281-2.

5. Hung H. T. Flipping the classroom for English language learners to foster active learning. Computer Assisted Language Learning. 2015. No. 28(1). Pp. 81-96.

6. Jdaitawi M. The Effect of Flipped Classroom Strategy on Students Learning Outcomes. International Journal of Instruction. 2019. Vol. 12. No. 3. Pp. 665-680. DOI: 10.29333/iji.2019.12340a.

7. Mahasneh O. M. The effectiveness of flipped learning strategy in the development of scientific research skills in procedural research course among higher education diploma students. Research in Learning Technology. 2020. Vol. 28. Pp. 1-17. DOI: $10.25304 /$ rlt.v28.2327.

8. Nouri. J. The flipped classroom: for active, effective and increased learning - especially for low achievers. International Journal of Educational Technology in Higher Education. 2016. No. 13. Pp. 1-10. DOI: 10.1186/s41239-016-0032-z.

9. O'Flaherty J., Phillips C. The use of flipped classrooms in higher education: a scoping review. The Internet and Higher Education. 2015. No. 25. Pp. 85-95. DOI: 10.1016/j.iheduc.2015.02.002.

10. Uzunboylu H., Damla Karagözlü D. Flipped classroom: A review of recent literature. World Journal on Educational Technology Current Issues. 2015. No. 7 (2). Pp. 142-147. DOI: 10.18844/wjet.v7i2.46. 
11. Yeung K., \& O’Malley P. Making «The Flip» work: Barriers to and implementation strategies for introducing flipped teaching methods into traditional higher education courses. New Directions for Institutional Research. 2014. No. 10(1). Pp. 59-63. DOI: $10.29311 /$ ndtps.v0i10.518.

12. Zainuddin Z., Halili S. H. Flipped Classroom Research and Trends from Different Fields of Study. International Review of Research in Open and Distance Learning. 2016. No. 17(3). Pp. 313-340. DOI: 10.19173/irrodl.v17i3.2274.

13. Zuber W. The flipped classroom, a review of the literature. Industrial and Commercial Training. 2016. No. 48(2). Pp. 97-103. DOI: 10.1108/ICT-05-2015-0039.

14. Wang Y. H. Could a mobile-assisted learning system support flipped classrooms for classical Chinese learning? Journal of Computer Assisted Learning. 2016. No. 32. Pp. 391-415. DOI: 10.1111/jcal.12141.

\section{References:}

1. Chua J. S. M., Lateef F. A. (2014) The flipped classroom: viewpoints in Asian universities. Education in Medicine Journal. No. 6 (4). Pp. 20-26. DOI: 10.5959/eimj.v6i4.316.

2. Clark K. R. (2015) The effects of the flipped model of instruction on student engagement and performance in the secondary mathematics classroom. Journal of Educators Online. No. 12(1). Pp. 91-115. DOI: 10.9743/JEO.2015.1.5.

3. Flores O., del-Arco I., \& Silva P. (2016) The flipped classroom model at the university: Analysis based on professors' and students' assessment in the educational field. International Journal of Educational Technology in Higher Education. No. 13(1), Pp. 1-12. DOI:10.1186/s41239-016-0022-1.

4. Goedhart N. S., Blignaut-van WestrhenenN., Moser C. et al. (2019) The flipped classroom: supporting a diverse group of students in their learning. Learning Environments Research. No. 22. Pp. 297-310. DOI: 10.1007/s10984-019-09281-2.

5. Hung H. T. (2015) Flipping the classroom for English language learners to foster active learning. Computer Assisted Language Learning. No. 28(1). Pp. 81-96.

6. Jdaitawi M. (2019) The Effect of Flipped Classroom Strategy on Students Learning Outcomes. International Journal of Instruction. Vol. 12. No. 3. Pp. 665-680. DOI: 10.29333/iji.2019.12340a.

7. Mahasneh O. M. (2020) The effectiveness of flipped learning strategy in the development of scientific research skills in procedural research course among higher education diploma students. Research in Learning Technology. Vol. 28. Pp. 1-17. DOI: $10.25304 /$ rlt.v28.2327.

8. Nouri J. (2016). The flipped classroom: for active, effective and increased learning - especially for low achievers. International Journal of Educational Technology in Higher Education. No. 13. Pp. 1-10. DOI: 10.1186/s41239-016-0032-z.

9. O'Flaherty J., Phillips C. (2015) The use of flipped classrooms in higher education: a scoping review. The Internet and Higher Education. No. 25. Pp. 85-95. DOI: 10.1016/j.iheduc.2015.02.002.

10. Uzunboylu H., Damla Karagözlü D. (2015) Flipped classroom: A review of recent literature. World Journal on Educational Technology Current Issues. No. 7 (2). Pp. 142-147. DOI: 10.18844/wjet.v7i2.46.

11. Yeung K., \& O’Malley P. (2014) Making «The Flip» work: Barriers to and implementation strategies for introducing flipped teaching methods into traditional higher education courses. New Directions for Institutional Research. No. 10(1). Pp. 59-63. DOI: $10.29311 /$ ndtps.v0i10.518.

12. Zainuddin Z., Halili S. H. (2016) Flipped Classroom Research and Trends from Different Fields of Study. International Review of Research in Open and Distance Learning. No. 17(3). Pp. 313-340. DOI: 10.19173/irrodl.v17i3.2274.

13. Zuber W. (2016) The flipped classroom, a review of the literature. Industrial and Commercial Training. No. 48(2). Pp. 97-103. DOI: 10.1108/ICT-05-2015-0039.

14. Wang Y. H. (2016) Could a mobile-assisted learning system support flipped classrooms for classical Chinese learning? Journal of Computer Assisted Learning. No. 32. Pp. 391-415. DOI: 10.1111/jcal.12141.

\section{Корницька Ю. А., Народовська О. М. Розвиток навичок читання: алгоритм організації в моделі перевернутого класу}

Розвиток навичок читання є однією з ключових иілей курсу англійської мови фахового спрямування, оскільки в умовах сьогодення студентам необхідо вміти обробляти значну кількість інформації під час навчання та в майбутньому в професійній діяльності. Нинішня зміна парадигми освіти стимулює викладачів до переорієнтаиї стратегій викладання та прийняття нових підходів, щзоб зробити процес навчання продуктивним та відповідним сучасному контексту. Дослідження підходу «перевернутий клас» підтверджують його значний потениіал для оновлення навчального процесу, підвищення його ефективності, збагачення та актуалізаиії. Підхід привертає все більше уваги з боку викладачів-практиків та науковиів. Презентуючи позитивні дослідження, науковці відзначають загальнопозитивний вплив моделі навчання «перевернутий клас» на результати навчання, ставлення студентів до навчального процесу та рівень їх задоволеності результатами порівняно з традиційними моделями. Однак відсутність чіткого розуміння щодо можливостей «перевернутого класу» для розвитку навичок читання та недостатній рівень технічних знань та навичок викладачів є одними з основних перепон для активного використання моделі в практичній діяльності. На основі практичного досвіду в роботі представлений алгоритм організації роботи для розвитку навичок читання в курсі іноземної мови фахового спрямування у форматі «перевернутий клас». Як технічне рішення в роботі представлено платформу Wizег.те., яка пропонує інструменти для розробки інтерактивних завдань та надає функиії, такі як додавання аудіоконтенту, відео, посилань та зображень. Сервіс дозволяє користувачам отримати інформацію про успішність та прогрес студентів та надавати зворотний зв'язок. Фукниіонал платформи надає можливість забезпечити індивідуалізацію роботи з кожним студентом та уможливлює самоаналіз, щуо є важливим компонентом процесу розвитку рефлексї та критичної самооцінки. Маючи зручний та інтуїтивно зрозумілий інтерфейс, платформа доступна для використання викладачам з базовим рівнем комп ютерної грамотності.

Ключові слова: англійська мова фахового спрямування, читання, перевернутий клас, технічне рішення, алгоритм, етапи, Wizer.me. 